\title{
John a Kent, the Wise Man of Westchester
}

\begin{abstract}
Anthony Munday's John a Kent and John a Cumber should be dated to the mid1590s, not 1590. I argue that it is the same play as The Wise Man of Westchester, presented by the Admiral's Men in 1594. The play's extraordinary popularity caused resentment among other playwrights and motivated their satirical attacks on Munday. Wise Man was revived in 1602 and the Chamberlain's Men produced another magician play The Merry Devil of Edmonton in 1603. This play clearly borrows from John a Kent and is further evidence that Wise Man and John a Kent are the same play.
\end{abstract}

The manuscript of John a Kent and John a Cumber written in the hand of Anthony Munday contains at the end a date in another hand that begins 'Decembris 159_' and ends with a figure that has caused considerable controversy among paleographic experts. The original finder and editor of the play was the notorious forger but diligent scholar J.P. Collier; in his 1851 transcription of the play he read it as $1595 .{ }^{1}$ This date was confirmed by Frederick Gard Fleay in 1591 and by W.W. Greg in 1904, who were both perhaps just following Collier. ${ }^{2}$ However, J.S. Farmer, who prepared the Tudor Facimile edition in 1912 and obviously had examined the manuscript carefully, also concurred with the 1595 reading. ${ }^{3}$ In 1916 a leading handwriting expert, Edward Maunde Thompson, declared firmly that the date was 1596; Greg, E.K. Chambers, and Muriel St Clare Bryne in the Malone Society transcription (1923) agreed. ${ }^{4}$ For a time this figure was accepted. In 1955, I.A. Shapiro published an article in which he argued strongly that the date was $1590.5^{5}$ Most scholars accepted his conclusion and for the next half century critics and historians commenting on the play mostly assumed this date. In 2006, however, the respected paleographer Grace Ioppolo stated that

Douglas H. Arrell (d.arrell@uwinnipeg.ca), a senior scholar and former chair of Theatre and Film at the University of Winnipeg, has published in Canadian theatre history, modern drama and dramatic criticism, and early modern English theatre history. 
the date should be read as $1595 .{ }^{6}$ More recently, MacDonald P. Jackson has made a strong case for re-reading the date as 1596 . He also argues that various stylistic features, such as the number of feminine endings in the play's verse and the percentages of 'hath' to 'has' and 'doth' to 'does', point to a date in the middle of the 1590 s. $^{7}$

Related to the issue of the date is the question of whether or not there are grounds to believe that this play is the same as The Wise Man of Westchester, an exceptionally successful play first presented by the Admiral's company in December 1594. This suggestion came first from Fleay, who was often highly speculative in his identification of plays in Henslowe's Diary. ${ }^{8}$ Greg, much more cautious, said Fleay was 'almost certainly right' in this case. In 1904 Greg assumed that the date on the manuscript indicated the date the text was written and so believed it was a 1595 revision of the original 1594 Wise Man. He thought the original might have included the fact that John a Kent had a wooden leg, since 'Kentes woden leage' is listed as a prop in the 1598 playhouse inventory formerly among the Henslowe papers. ' Later he put back the writing of John a Kent to 1590 or earlier and suggested 'provisionally' that Wise Man was a 1594 revision, perhaps by a different author. ${ }^{10}$ Chambers was somewhat noncommittal but seemed to lean towards accepting that the extant play was Wise Man. He suggested that the lack of reference to the wooden leg might relate to the fact that 'two or three leaves of the MS appear to be missing'. He noted that the date he read as 1596 may have been a later addition to the manuscript, not the date it was completed, and ignored Greg's suggestion of a 'revision.'11

While Shapiro's date held sway among scholars, the identification of the play with Wise Man seemed very improbable; in 1984, for example, Roslyn Knutson roundly attacked the theory. ${ }^{12}$ It is hard to think why a date earlier than the time the manuscript was written would be added to it (though we do not know the purpose of the date and such an insertion is not impossible). If either Ioppolo's or Jackson's rereading of the date is correct, we must return to The Wise Man of Westchester question, since a reason that a date later than the writing out of the play might have been added at the end of the manuscript is not too difficult to imagine. For example, we know that Edward Alleyn, the company's leading actor, later owned the playbook and perhaps he acquired it on this date. Although I cannot comment on the palaeographic issue, or the stylistic ones raised by Jackson, in this essay I will present more reasons for dating the play to the middle of the 1590s. I will 
also argue that it probably is the same play as The Wise Man of Westchester produced with such great success in 1594 .

A number of prima facie factors suggest that John a Kent and John a Cumber and The Wise Man of Westchester might be alternative titles for the same play. The text, at line 1381, refers to John a Kent, who is clearly the play's central figure, as a wise man; 'wise man' in this period may denote 'A man versed or skilled in hidden arts, as magic, witchcraft and the like' (OED 3). The play takes place in and around Chester (also known as Westchester or West Chester) where he appears to live. ${ }^{13}$ The manuscript seems to be a playbook used in production; although the playhouse notations are sparse, this fact is not unusual in the surviving playbooks according to William B. Long. ${ }^{14}$ Quite possibly, the play was performed by the Admiral's Men, who produced many of Munday's plays in the later 1590s. The handwriting of some of the stage directions appears on other stage documents; Greg believes it is 'Hand C' in The Book of Sir Thomas More, and the 'plot' of The Seven Deadly Sins, Part Two. ${ }^{15}$ While the company ownership of these texts is controversial, at least one document written by Hand C, the 'plot' of Fortune's Tennis, Part Two, seems definitely associated with the Admiral's Men. ${ }^{16}$

There are many examples in the Diary of the names of plays being changed or of plays being given alternative titles. Hand $\mathrm{C}$ seems to have been a bookkeeper or prompter and the fact that the title is in his hand suggests that the play went into rehearsal as John a Kent and John a Cumber. The company sometimes gave new names to plays even at this late stage. For example, in November 1599 Henslowe records a number of payments for Haughton and Day's play The Tragedy of Thomas Merry, often referred to as Merie, until 'full payment' on December 6; however, sometime between the tenth and the eighteenth of January 1599/1600 he paid the revels office for licensing 'Beches Tragedy', presumably the same play since Merry was the perpetrator and Beeches the victim in this real-life murder story. ${ }^{17}$ Given the rapid progress from script to production in this period, the play probably was in preparation, if not in performance, at this point. Throughout the history of theatre, plays often have had their names changed in rehearsal; at this point many more people become acquainted with the play and become concerned about its potential success at the box-office. What seemed an appropriate title to the author may not seem so to those directly involved in production. The fact that the bookkeeper did not trouble to change the title on the manuscript is admittedly puzzling but as Long notes it is typical of the surviving playbooks that no time is wasted making corrections that do not affect performance. 
Although the playbook was clearly used as a determinant of words spoken and for certain stage actions, it was not used as a prompt book defining and recording the production as in later theatre. ${ }^{18}$

John a Kent was a legendary figure about whom stories were still being told in the Welsh border counties into the nineteenth century. ${ }^{19}$ It seems likely that The Wise Man of Westchester was about this celebrated 'wise man'; there surely were not two such figures from the area. There may well have been ballads about John a Kent, ballads that referred to him as the Wise Man of Westchester, as there also undoubtedly were ballads about another character in the play, Ranulph Earl of Chester; ${ }^{20}$ although none about either man are extant, Collier in his edition of the play argues strongly for the likelihood that they once existed, stressing that very little of the ballad and chapbook materials of the era survive. ${ }^{21}$ Munday himself wrote ballads (none of which are extant) and the play, with its simple language, abundant use of rhyme, and frequently patterned language and stage action, has overtones of the ballad, as the play's modern editor, Arthur E. Pennell, notes. ${ }^{22}$ John's initial appearance curiously dressed in green and pretending to be a highwayman evokes the ballad world of Robin Hood that Munday later exploited in his earl of Huntington plays.

Nothing in the surviving stories about John a Kent indicates that he had a wooden leg and I suggest this prosthesis is a red herring. Nowhere in the play is John a Kent referred to as 'Kent'. Even in the speech prefixes and stage directions he is John and he is always referred to as John, John a Kent, or Master John, in the dialogue. 'Kent' is not his last name and he would not conventionally be called by it. ${ }^{23}$ It seems much more likely that the Kent who had a wooden leg, as mentioned in the inventory, was a character in one of the many non-extant plays presented by the Admiral's in this period, perhaps an earl of Kent since referring to him as 'Kent' in that context would be normal.

My discussion takes as a starting point the fact that in the intense commercial competition of the 1590s, one company did not hesitate to take features from successful plays presented by the other. This phenomenon is apparent in what is known of the repertoires of the Admiral's Men and the Lord Chamberlain's Men. As Knutson has noted, if one company has a successful play about Richard III, the other may present one also. If Roman plays, or revenge tragedies, or biblical plays seem to be popular with one company, the other will present versions of their own. ${ }^{24}$ I suggest that this 'stealing' from what was successful in the other company was quite pervasive, especially during 
the heady period of the 1590s when plays were being churned out as fast as possible to meet the demand of the companies now permanently resident in London, and that this phenomenon could be used to help us date plays such as John a Kent. Of course, scholars have long looked for influence of one play on another as a means of trying to date plays but the notion of 'stealing' is slightly different and perhaps more reliable as a dating tool. Not just a matter of finding verbal or thematic parallels between plays, this approach brings in a theatre history dimension not usually evident in studies that merely compare texts since it takes into account what is likely to be stolen and who would steal it. The key features of this kind of stealing would seem to be: the play being stolen from was very successful; the play containing the stolen material is presented by a rival company within a year or two of the first; and the stolen elements are aspects of the play that are novel and notable, including characters, plot devices, milieux, even jokes and stage tricks, that the playwright doing the stealing can appropriate for his own audience.

To illustrate the difference between 'influence' and 'stealing' as dating tools, consider two contrasting examples. In his edition of Marston's Antonio and Mellida, G.K. Hunter notes: 'The reminiscence of Sylvester's Du Bartas at line 58 of the Induction (if it be allowed) indicates that the writing comes after $1598 .{ }^{25}$ Marston's line is: 'you shall see me prove the very periwig to cover the bald pate of brainless gentility' (0.57-8). In Josuah Sylvester's translation from Guillaume Du Bartas entitled Essay of the Second Week (published 1598) appear the words 'perriwig with wool the bald-pate Woods'. ${ }^{26}$ Possibly Marston is consciously or unconsciously borrowing words from Sylvester's very popular work, which according to its modern editor, Susan Snyder, was read by 'everyone with any pretensions to a literary education'; ${ }^{27}$ also possibly (as Hunter's qualifying 'if it be allowed' indicates) the similarity is merely a coincidence, or both authors are remembering a third work, perhaps one of the many Elizabethan texts that do not survive. We don't know when Marston read Sylvester or whether he read him at all. We do not know the context of the borrowing, or indeed anything except the verbal similarities of the texts. There are too many questions to feel sure of this repetition as an indication of chronology. Contrast this example with the line 'I knew thee, Mall, now by my swoord I knew thee' (1. 1426) ${ }^{28}$ from the anonymous play Look About You as evidence that it is later than Henry IV, Part One, in which occurs the line 'By the Lord, I knew thee as well as he that made ye'(2.4.258-9). ${ }^{29}$ The line in Look About You occurs when Lord Fauconbridge discovers that 
the 'merchant's wife' whom he is seeking to seduce is in fact his own wife in disguise; Falstaff speaks his line when he discovers that the men who robbed him were in fact Prince $\mathrm{Hal}$ and Poins in disguise. The latter was the climax of the funniest scene in a play that we know was a huge success; it was presented by the Chamberlain's Men, rivals to the Admiral's Men who presented Look About You. Many other features of Look About You seem stolen from Henry IV, Part One, beginning with its novel genre: an English history play in which comedy plays a central role. ${ }^{30}$ Look About You features an English king called Henry who is estranged from his son, also called Henry; the two are reconciled at the end when the son repents his rebellion. There is a central role for a likeable rogue (Skink) much given to soliloquizing, a tavern scene (with a tapster who says 'Anon, anon sir' [1. 1532]), not one but two amateur highway-robbery scenes, and an impulsive young nobleman obsessed with his honour (Prince John) who is actually referred to as a 'hot spur' (1. 72). The play illustrates just how shameless attempts to cash in on the success of a rival company could be.

Collier first noted an example of what could be such stealing in John a Kent, and J.W. Ashton developed the idea more fully in 1929.31 The scene in which Turnop and the other artisans argue as to who is to speak to welcome the arrival of Morton and Pembroke strongly resembles the scene in the anonymous play $A$ Knack to Know a Knave in which 'the Mad Men of Goteham', a smith, cobbler, and miller, argue about who is to present a petition to the king who is arriving at their town (ll 1363-1411). ${ }^{32}$ Ashton points out many detailed similarities between the two scenes. ${ }^{33}$ What makes this stealing seem particularly likely is that it appears that the Knack scene was famous. When the play was printed in 1594 the title page advertised that the play includes 'Kemps applauded Merrimentes of the men of Goteham, in receiving the King into Goteham' (A1r). This piece of sketch comedy, entirely irrelevant to the rest of play, was clearly a star turn for Will Kemp and it is typical of the unbridled competition among companies and playwrights that John a Kent should so shamelessly steal from it.

A Knack to Know a Knave was presented by Strange's Men (marked as 'ne' by Henslowe, usually meaning 'new') on 10 June 1592 and last appears in the records on 24 January 1592/93. It may have moved to the Chamberlain's company with Will Kemp in 1594. The most likely scenario is that Munday wrote John a Kent sometime after June 1594 for the Admiral's, now rival to Kemp's company. At least, if Collier and Ashton are right, the play should be dated sometime after June 1592. 
In a more basic way John a Kent also steals from the two Friar Bacon plays, Friar Bacon and Friar Bungay and John of Bordeaux. The first was associated with the Queen's Men; the latter was probably presented by Strange's Men and was presumably lost to the Admiral's company after 1594. Munday's play may have been an attempt to replace it. ${ }^{34}$ John a Kent follows the basic pattern of Robert Greene's plays about Friar Bacon: a see-saw competition between a good magician and bad magician, ending with the humiliation of the bad one. Also part of the formula is a serious love plot with a happy ending interspersed with scenes of low comedy. But Munday was no 'university wit' and the tone of his play is very different from Greene's: no Latin, no Ovidian allusions, no academic discussions of magic. His homely ballad style was actually a better fit with the subject matter than was Greene's, whose simple country-girl heroine must make references to 'Phoebus' $(3.14-45)^{35}$ and 'Paris, when, in grey, / He courted Oenon' (3.64-5), and so on. Magic and farce likely account for the popularity of Greene's plays, and Munday's John a Kent may have been even more to the taste of the audiences to whom this kind of play appealed.

The most significant 'stealing' in the play is from A Midsummer Night's Dream. The character of Shrimp in John a Kent strongly resembles Shakespeare's Puck. Like Puck he is a sprite who serves a mostly benevolent master with supernatural powers; he frequently is invisible, mischievously creating confusion among the humans; he leads people astray in the woods and eventually puts them to sleep; like Puck he creates comedy by tricking the artisan characters, substituting for their wedding day serenade of the bridegrooms a song announcing that their brides have left them.

Thinking John a Kent was written by 1590, a number of scholars have suggested that Shakespeare was imitating Munday rather than the other way around. ${ }^{36}$ Possibly so, but I do not think it is bardolatry to say that it is unlikely. We know where Shakespeare got Puck: from the rich body of folklore surrounding Robin Goodfellow and 'the Poucke'. ${ }^{37}$ Munday's Shrimp whose name merely indicates his small size ${ }^{38}$ — has no such source; he seems merely a pale copy of an appealing feature of A Midsummer Night's Dream, created by a writer notorious for his lack of originality (see below).

The notion that Munday is stealing from A Midsummer Night's Dream seems to me to be confirmed by the fact that the mischievous sprite is not the only feature John a Kent has in common with Shakespeare's play. As well as borrowing from Will Kemp's Knack to Know a Knave skit in his portrayal of the artisan clowns, Munday also seems to be borrowing from what was 
no doubt another of Kemp's starring roles, that of Bottom. We see 'Turnop with his crewe of Clownes' in chaotic preparations for a sort of pageant in honour of the upcoming aristocratic wedding and the comically bad results in Turnop's speech beginning 'Lyke to the Cedar in the Loftie Sea, / or milke white mast vppon the humble mount' (1l 373-4). ${ }^{39}$ This is very much in the vein of the absurd attempts at poetic language in the Dream, and calls forth a Theseus-like comment from Oswen: 'My Lordes, my fathers tenants after their homely guise, / welcome ye with their countrey merriment, / How bad so ere, yet must ye needes accept it' (ll 379-81). Munday did not get this aspect of the scene from $A$ Knack to Know a Knave, where there is no show involved, just a brief humorously anticlimatic greeting to the King. The fact that two essentially unrelated motifs from Dream reappear in this play strongly suggests that Munday was stealing from it. Of course, we don't know for sure that $A$ Midsummer Night's Dream was a highly successful play but its mention in Francis Meres's Palladis Tamia and the fact that it continued to be performed by the company (probably at court in 1603/04 and again in 1630) suggest that it was.

Most students of A Midsummer Night's Dream place it sometime in the mid-1590s, before the publication of Palladis Tamia in 1598. Most make the earliest possible date for the play sometime after October 24, 1594, when an account was published of the baptismal feast of Prince Henry in Scotland, where the original plan of having a chariot pulled by a lion was abandoned because of concern that his presence might have brought 'some feare to the nearest'; Harold Brooks thinks this incident must have lodged in Shakespeare's mind and given rise to the concern of the mechanicals that their lion might frighten the ladies. ${ }^{40}$ Peter Holland, the play's more recent editor, rejects many of the supposed topical allusions found in the play by earlier scholars but nonetheless does seem to accept this one. ${ }^{41}$ I suggest that the similarity of the lion references is a not very remarkable coincidence and that there are stronger reasons for thinking that a play first presented on 3 December 1594 contained material stolen from the Dream, which means that it was probably first presented earlier than most scholars have assumed, perhaps in the summer of 1594 in the early days of the newly-formed Chamberlain's company. And so the issue of whether or not John a Kent is Wise Man has a bearing on the dating of a Shakespeare play.

A number of references to Munday in the late 1590s seem to me to support the idea that he wrote The Wise Man of Westchester. It was by far the most successful new play presented by the Admiral's company in 1594-7, attracting 
over forty percent more gallery receipts than the next most popular play (Seven Days of the Week) and receiving more than double the number of performances of the average successful new play. ${ }^{42}$ We don't know what Munday was writing prior to 1597 , since Henslowe makes almost no reference to playwrights before then. But he was clearly a very prominent playwright. Consider Meres's catalogue:

the best for Comedy amongst us bee Edward Earle of Oxforde, Doctor Gager of Oxforde, Maister Rowley once a rare Scholler of learned Pembrooke Hall in Cambridge, Maister Edwardes one of her Majesties Chappell, eloquent and wittie John Lilly, Lodge, Gascoyne, Greene, Shakespeare, Thomas Nash, Thomas Heywood, Anthony Mundye our best plotter, Chapman, Porter, Wilson, Hathway, and Henry Chettle. ${ }^{43}$

The last seven playwrights on the list all wrote for the Admiral's company and the fact that Munday is given the distinction of his full name and the surprising words of praise suggest that he is the outstanding figure among them.

The extraordinary extent to which he was attacked by his fellow playwrights confirms his prominence. In Jonson's The Case is Altered one scene portrays Munday as Antonio Balladino. His name makes fun of the fact that Munday wrote ballads, clearly viewed by the more literary playwrights as the lowest form of authorship. The play also satirizes Munday's no doubt lucrative work as author of London civic pageants. In particular, it emphasizes two features of Munday's dramatic writing. His plays are very popular, especially with lower class audience-members like the groom Onion, who is an illiterate clownish character; he writes in a 'plain' style and rejects the fashionable 'humours' plays that appeal to gentlemen. And he is proud of the fact that what he writes is 'stale' — 'such things euer are like bread, which the staler it is, the more holesome' (2.45-6); 44 'Why, I'le tell you, M. Onion, I do vse as much stale stuffe, though I say it myselfe, as any man does in that kind' (2.48-9). This portrayal suggests that Munday was a notably popular playwright whose works were highly derivative and had no pretensions to literature.

The portrayal of Munday as the playwright Posthaste in Histrio-Mastix conveys a very similar picture. ${ }^{45}$ The plebian Gulch says of his work, shown as childishly silly in the play: 'Well fellowes, I never heard happier stuffe, / Heer's no new luxurie or blandishment, / But plenty of old Englands mothers 
words' (C1v). ${ }^{46}$ As in The Case is Altered he is made fun of as a 'pageanter' (E4v) and an author of ballads (F2v; H1v-H2r). Chrisoganus's denunciation of contemporary playwriting seems directed specifically at the highly successful Munday:

Write on, crie on, yawle to the common sort

Of thickskin'd auditours: such rotten stuffs,

More fit to fill the paunch of Esquiline,

Then feed the hearings of judiciall eares,

Yee shades tryumphe, while foggy Ignorance

Clouds bright Apollos beauty : Time will cleere,

The misty dullnesse of Spectators Eeys,

Then woefull hisses to your fopperies,

$\mathrm{O}$ age when every Scriveners boy shall dippe

Prophaning quills into Thessaliaes Spring,

When every artist prentice that hath read

The pleasant pantry of conceipts, shall dare,

To write as confident as Hercules.

When every Ballad-monger boldly writes :

And windy froth of bottle-ale doth fill

Their purest organ of invention:

Yet all applauded and puft up with pryde,

Swell in conceit, and load the Stage with stuffe,

Rakt from the rotten imbers of stall jests :

Which basest lines best please the vulgar sence

Make truest rapture lose preheminence.

The context of this speech is that Sir Oliver Owlet's players have just refused to pay ten pounds for Chrisoganus's play, saying they have no need for his works 'while goosequillian Posthast holds his pen'. Thus although Christoganus is attacking contemporary playwriting in general, his remarks particularly refer to one very successful playwright, one who is a mere 'Balladmonger', whose plays appear to dominate the stage, are popular with the common sort of audience member, and are 'Rakt from the rotten imbers of stall jests'. Whoever wrote this speech and the Balladino scene in The Case is Altered clearly express the resentment of the more sophisticated playwrights at Munday's enormous popularity and financial success in spite of the simplistic and derivative nature of his writing. 
Commentators on Munday have given a number of reasons for the amount of attention given to him in these two plays. Many think that the Antonio Balladino satire derives from some personal animosity between Munday and Jonson, perhaps resentment on the part of Jonson that Munday was called 'our best plotter. ${ }^{47}$ Some have suggested that Jonson's attack derived from the fact that he was a recently converted Catholic and Munday was a Protestant poursuivant. ${ }^{48}$ Donna B. Hamilton, who believes Munday was a secret Catholic, explains the scene as the openly Catholic Jonson seeking to "out" Munday in a most public and defiant manner for closeting his Catholicism in the safety of loyalty. ${ }^{49}$ Tracey Hill thinks it derives in part at least from the fact that 'Jonson regarded Munday as a rival for civic patronage. ${ }^{50} \mathrm{I}$ suggest that the scene should be taken at face value: it expresses resentment at the fact that Munday was the author of plays that were inferior and yet outstandingly successful. This view seems to be confirmed by the fact that the Histrio-Mastix scenes make exactly the same point. Chrisoganus has often been seen as a portrait of Jonson and perhaps the views expressed in the speech quoted above echo those of Jonson. But even so, the passion of this speech proclaims that the author of the play shares Chisoganus's anger at the success of inferior playwriting. Nothing in either scene suggests an ulterior religious or personal motive for the satire; plenty suggests that the motive was simply resentment at Munday's undeserved enormous success.

Presumably one of the playwrights listed by Meres wrote The Wise Man of Westchester. Munday was probably writing for the Admiral's company during this period and no one on the list is more likely to have written it. The best explanation for Munday's treatment in these two plays is that he wrote, among other works, this phenomenally successful play.

Very likely this play was John a Kent, which survives in a playbook in Munday's hand, which both Jackson and I have argued was written in the mid-1590s, and which is about a wise man of Westchester. Admittedly more than one play about John a Kent could have existed; indeed, such a popular play as Wise Man might well have had a sequel. Could John a Kent be a sequel of Wise Man, as has been suggested?51 Marlowe's Tamburlaine, Part Two created a fashion for writing sequels to plays that had proved popular. In almost every case, the sequel is set chronologically later than the original and contains references back to it. These references, usually to the key events of what has become Part One, remind the audience of the popular earlier work and are part of the attempt to exploit its success. The most obvious model that Munday might have chosen had he decided to write a sequel to Wise 
Man was John of Bordeaux; clearly an unplanned sequel, it contains a number of references back to Bacon's exploits in Friar Bacon and Friar Bungay. ${ }^{52}$ The fact that there are no references at all to past events in John a Kent, in particular none to John's past magical triumphs, makes it almost certain that this is not a sequel. The reverse is also unlikely: Wise Man was surely not a sequel to John a Kent. Few Shakespeare scholars would place A Midsummer Night's Dream earlier than the summer of 1594 and time does not seem to allow for a play imitating it to be such a success that it warranted a sequel by early December of that year when Wise Man was produced. The highly successful Wise Man was more likely to have had a sequel than be itself a sequel; the Diary certainly bears evidence that sequels almost never match the success of the original. Also, John a Kent was probably an Admiral's play but no sign of it appears in Henslowe's schedule; one would expect the company to programme the two plays on successive days, as they often did other two-part plays.

John a Kent could certainly have been the popular mediocre work that seems indicated by The Case is Altered and Histrio-Mastix references. It is a plainly written play whose language has more in common with popular ballads than with Shakespeare or Marlowe. The script contains no references to fashionable topics such as 'humours' and no allusions to Ovid or Latin tags such as are found in the Friar Bacon plays and Doctor Faustus. It certainly deserves the criticism of being highly derivative, borrowing its main plot structure from the Friar Bacon plays as well as features from $A$ Knack and Dream; the 'wise men of Goteham' skit could certainly qualify as a 'stale jest' recycled in this play. If this play were hugely successful, one could well see that it might have provoked from playwrights like Jonson and Marston the backlash that we see in the Balladino and Chrisoganus scenes.

On 19 September 1601, the Admiral's Men (now at the Fortune) paid Edward Alleyn two pounds for The Wise Man of Westchester; presumably Alleyn owned the playbook, had taken it with him when he left in 1597, and now wished to act again in the play after rejoining the company. ${ }^{53}$ In November 1602, Bird and Rowley were paid for additions to Doctor Faustus, presumably because Alleyn was planning to return to another of his famous roles. ${ }^{54}$ Sometime before 1604 the Chamberlain's Men presented the anonymous play The Merry Devil of Edmonton. As Knutson points out, the first act of this play clearly steals from Faustus, as a devil confronts the famous magician/scholar Peter Fabel in his chamber and demands his soul. 55 What Knutson does not bring out fully, however, is the extent to which 
the rest of the play steals from John a Kent and John a Cumber. The two plays tell essentially the same story: a benevolent, wryly comical, and apparently omniscient magician helps a young couple to elope in the face of the girl's father's determination that she marry someone else. Just as John a Kent engineers things so that, with broad irony, Marian and Sidanen are delivered by Marian's father to their lovers to be married, so in this play Fabel arranges things so that Millicent's lover (disguised as a friar) is delivered to her by her father. Both plays are set in a Robin Hood world where there are still friars, nuns, and abbots, and many events take place in the woods. Both are interspersed with the antics of a quartet of low comedians. Like John a Kent, the Merry Devil contains many references to the amazing magical powers of the central figure, but in practice his magic is limited, restricted in this case to omniscience, disguises, and general manipulation of the action. And just as the legendary Peter Fabel was the Merry Devil of Edmonton, the legendary John a Kent was (perhaps) the Wise Man of Westchester. The fact that this famous Admiral's play was revived in time to be a model for the Chamberlain's Merry Devil, which has many features that appear to be taken from John a Kent, does not prove that Wise Man and John a Kent are the same but it certainly is consonant with such a theory.

The Merry Devil of Edmonton was an extremely popular play, especially with lower class theatre goers. Middleton mentions it in 1604 along with A Woman Killed with Kindness as the sort of play a servant might be likely to enjoy. ${ }^{56}$ It was published in at least six editions and in 1616 Jonson refers to it in the prologue to The Devil is an Ass as the audience's 'deare delight' (0.22). ${ }^{57}$ It stayed in the repertoire of the King's Men, being produced at court in 1618, 1631, and 1638 . To the modern reader it seems a very slight play; the characterization is perhaps better than in John a Kent but the construction is worse. Perhaps this answers one final objection to the identification of John a Kent with the Wise Man. To the modern reader, John a Kent does not seem to have the interest that could have given rise to the extreme popularity of the Wise Man. But we know of a play very similar to John a Kent and of not much greater merit that was extremely successful. This fact suggests that we need to rethink what made for popular success in the early modern theatre. Clearly the magician character and the portrayal of magic had a very strong appeal to some audience members; tame as it seems, Wise Man was the Harry Potter of the day. The simple stories of lovers separated and united and the scenes of low comedy no doubt contributed to the plays' popularity also. Theatre history contains many examples of successful plays 
whose popularity remains a puzzle to the modern critic. The anonymous Mucedorus could be cited as an example from the early modern period. The most popular show on Broadway in the 1920s was not Showboat or any of the famous plays and musicals of the period but Abie's Irish Rose by Anne Nichols. Few today have read it, but one gathers it is a slight sentimental comedy about lovers separated by their parents and eventually united; it ran for 2327 performances, making it still the third longest running non-musical in the history of Broadway. In its day it too was looked down upon, much as Munday's plays apparently were. ${ }^{58}$ The popularity of works widely judged as inferior has always evoked anger from the serious artists who feel their craftsmanship and high artistic aspirations have been undervalued by audiences. This anger is exactly what we see in The Case is Altered and Histrio-Mastix. The best explanation for the bitter reaction provoked by Munday's modest playwriting efforts is that they had an astonishing success, the success of The Wise Man of Westchester.

\section{Notes}

1 Anthony Munday, John a Kent and John a Cumber: A Comedy, ed. J. Payne Collier (London, 1851), vi.

2 Frederick Gard Fleay, A Biographical Chronicle of English Drama 1559-1642, 2 vols (1891; rpt New York, 1973), 2.114; Walter W. Greg (ed.), Henslowe's Diary, 2 vols (1904-8; rpt New York, 1977), 2.172.

3 Anthony Munday, The Book of John-a-Kent and John-a-Cumber, ed. John S. Farmer, Tudor Facimile Texts (London, 1912; rpt New York 1970), preface.

4 Edward Maunde Thompson, 'The Autograph Manuscripts of Anthony Mundy', Transactions of the Bibliographical Society 14 (1919), 326-7; W.W. Greg, Dramatic Documents from the Elizabethan Playhouse; Stage Plots; Actors' Parts; Prompt Books, 2 vols (Oxford 1969), 1.223; E.K. Chambers The Elizabethan Stage, 4 vols (1923; rpt Frome, 1961), 3.446; Muriel St Clare Bryne (ed.), John a Kent and John a Cumber, Malone Society Editions (London, 1923), 51.

5 I.A. Shapiro, 'The Significance of a Date', Shakespeare Survey 8 (1955), 100-5.

6 Grace Ioppolo, Dramatists and their Manuscripts in the Age of Shakespeare, Jonson, Middleton and Heywood (New York, 2006), 101.

7 MacDonald P. Jackson, 'Deciphering a Date and Determining a Date: Anthony Munday's John a Kent and John a Cumber and the Original Version of Sir Thomas More', 
Early Modern Literary Studies 15.3 (2011), 2 [http://purl.org/emls/15-3/jackdate .htm].

8 Fleay, A Biographical Chronicle of English Drama, 2.114.

9 Greg (ed.), Henslowe's Diary, 2.172.

10 Greg, Dramatic Documents, 1.224.

11 Chambers, The Elizabethan Stage, 3.446.

12 See Roslyn L. Knutson, 'Play Identifications: The Wise Man of West Chester and John a Kent and John a Cumber; Longshanks and Edward I', Huntington Library Quarterly 47.1 (Winter 1984), 1-11.

13 From the fifteenth to the eighteenth centuries, Chester was often referred to as Westchester or West Chester. See J. McN. Dodgson, The Place-Names of Cheshire, Part V (Cambridge 1981), 5-7. The location is once referred to in the play as 'west chester' (1 55).

14 William B. Long, 'John a Kent and John a Cumber: An Elizabethan Playbook and Its Implications', in W.R. Elton and William B. Long (eds), Shakespeare and Dramatic Tradition (Newark, NJ, 1989), 127-8.

15 Greg, Dramatic Documents, 1.240.

16 Ibid, 1.131.

17 This information is derived from R.A. Foakes (ed.), Henslowe's Diary, 2nd ed. (Cambridge, 2002).

18 William B. Long, "Precious Few”: English Manuscript Playbooks', in David Scott Kastan (ed.), A Companion to Shakespeare (Oxford, 1999), 416-18.

19 See Collier (ed.), Introduction, John a Kent and John a Cumber, xxii-xxvi, and Arthur E. Pennell (ed.), An Edition of Anthony Munday's John a Kent and John a Cumber (New York, 1980), 225-7.

20 See J.W. Ashton, 'Jack-a-Kent: the Evolution of a Folk Figure', Journal of American Folklore 47 (1934), 364.

21 Collier (ed.), Introduction, John a Kent and John a Cumber, xv-xvi.

22 Pennell (ed,), An Edition of Anthony Munday's John a Kent, 39-40.

23 Of course he has nothing to do with the county of Kent. His name may derive from the fifteenth century Welsh poet with whom he was confused or conflated, Sion Cent or Gwent. Gwent was an ancient Welsh kingdom. See 'Sion Cent' in the $\mathrm{Na}$ tional Library of Wales: Welsh Biography Online.

24 Roslyn L. Knutson, The Repertory of Shakespeare's Company 1594-1613 (Fayetteville, AR, 1991), 40-55. This intense commercial competition was not incompatible with warm personal relations between the personnel of rival companies or cooperation between them for their mutual benefit, as Knutson has more recently emphasized in Playing Companies and Commerce in Shakespeare's Time (Cambridge, 2001), 21-47. 
25 John Marston, Antonio and Mellida, ed. G K Hunter (Lincoln NE, 1965), x.

26 Josuah Sylvester (trans.), The Divine Weeks and Works of Guillaume de Saluste Sieur Du Bartas, ed. Susan Snyder, 2 vols (Oxford, 1979), 1.385.

27 Ibid, 1.74 .

28 Anonymous, Look About You, ed. W.W. Greg, Malone Society Editions (London, 1913).

29 William Shakespeare, Henry IV, Part One, ed. David Bevington (1987; rpt New York, 1994).

30 It is true that Shakespeare probably derived the comic element in the play from the earlier Queen's Men play, The Famous Victories of Henry the Fifth (c. 1585), but in the context of the history plays on stage in the 1590s, including his own Henry VI plays, Richard III, Richard II, Edward II, and Thomas of Woodstock, the extent and centrality of the Falstaff scenes must have seemed novel to audiences.

31 Collier (ed.), Introduction, John a Kent and John a Cumber, viii; J.W. Ashton, 'The Date of John a Kent and John a Cumber', Philological Quarterly 8 (1929), 225-32.

32 Anonymous, A Knack to Know a Knave, Malone Society Editions (London, 1963).

33 Ashton, 'The Date of John a Kent and John a Cumber', 227-9.

34 It is true that in December 1602 the Admiral's company hired Middleton to write a prologue and epilogue for 'the play of bacon for the cort' (Foakes (ed.), Henslowe's Diary, 207); the likely reference is to Friar Bacon and Friar Bungay, since the play is described in the quarto of 1630 as 'lately plaid by the Prince Palatine his Servants', the successor to the Admiral's. See C.F. Tucker Brooke and Nathaniel Burton Paradise (eds), English Drama 1580-1642 (Boston, 1933), 70. How the company obtained the play we do not know but they do not seem to have owned it in the mid-1590s since there is no sign of their performing it during the period for which Henslowe kept his schedule of performances (1594-97).

35 The Honourable History of Friar Bacon and Friar Bungay, in Brooke and Paradise (eds), English Drama, 71-96.

36 See, for example, Shapiro, 'The Significance of a Date', 103 and David Womersley, 'Shakespeare and Anthony Munday', in David Womersley and Richard McCabe (eds), Literary Milieux: Essays in Text and Context Presented to Howard Erskine-Hill (Newark, NJ, 2008), 82. In the Arden edition of A Midsummer Night's Dream (1975; rpt London, 2007), Harold Brooks gives a full list of the similarities between the two plays; he leaves open the issue of who influenced whom (lxiv-lxvi). Peter Holland, editor of the Oxford edition (Oxford, 1994), seems to lean toward the belief that Shakespeare was influenced by Munday (39-40).

37 See Holland (ed.), A Midsummer Night's Dream, 35-9.

38 The $O E D$ gives the meaning of 'a small or puny person' dating back to Chaucer. 
39 All references are to Pennell (ed.), An Edition of Anthony Munday's John a Kent.

40 Brooks (ed.), A Midsummer Night's Dream, xxxiv-xxxv.

41 Holland (ed.), A Midsummer Night's Dream, 110.

42 The Wise Man of Westchester earned Henslowe a total of $£ 55$ as compared to $£ 38$ 17s for The Seven Days of the Week. The number of performances of the ten most successful new plays were: The Wise Man of Westchester 32, Belledon 24, Seven Days of the Week 22, The Knack to Know an Honest Man 21,The Blind Beggar of Alexandria 19, Crack Me This Nut 17, Alexander and Lodowick 15, Longshanks 14, Chinon of England 14, Henry V13.

43 Francis Meres, Palladis Tamia: Wits Treasury: Being the Second Part of Wits Commonwealth (London, 1598; rpt New York, 1973), 283v.

44 Ben Jonson, The Case is Altered, in C.H. Herford and Percy and Evelyn Simpson (eds), Ben Jonson, 11 vols (Oxford, 1954-60), 3.94-190.

45 The date and authorship of both the Antonio Balladino scene in The Case is Altered and the Sir Oliver Owlet's players scenes in Histrio-Mastix are disputed. Who wrote these scenes does not matter much to my argument but the timing does. Although the former scene seems likely to have been added after the play was first produced, I feel that it must be dated between 1598 and 1603. Clearly it postdates September 1598 since it alludes to Meres's mention of Munday as 'our best plotter' but not by too many years or this topical reference would lose its effectiveness, as would the references to the fashionableness of humours plays. Both these points are made by Celeste Turner in her study of Munday, Anthony Mundy: An Elizabethan Man of Letters (Berkeley, 1928), 124. Most Munday scholars believe he had abandoned playwriting by 1603 - eg, Tracey Hill, Anthony Munday and Civic Culture (Manchester, 2004), 125 — and it seems unlikely the intense attacks on him would have been written after he was no longer in the business. The criticisms of Munday in Histrio-Mastix are so similar to those in the Antonio Balladino scene that one feels they must have been produced at about the same historical moment. I find Philip K. Finkelpearl's suggestion that the play was written by Marston for performance the Middle Temple in 1598-99 quite convincing; see John Marston of the Middle Temple: An Elizabethan Dramatist in His Social Setting (Cambridge, MA, 1969), 120-4. The traditions of this kind of performance and the fact that it would be Marston's first dramatic effort may explain some of the oddities of the play and the differences in style from Marston's other works, as noted by Knutson (Playing Companies and Commerce in Shakespeare's Time, 75-102). Given the literary pretentions and habit of theatre-going among students of the Inns of Court, the attack on the low quality of popular playwriting as exemplified by Munday would not be unexpected. 
46 Anonymous, Histrio-Mastix (1610; rpt Tudor Facimile Texts, 1912; rpt New York, 1970).

47 For example, Fleay, A Biographical Chronicle of English Drama, 1.109.

48 See, for example, Frank L. Huntley, 'Ben Jonson and Anthony Munday, or, The Case Is Altered, Altered Again', Philological Quarterly 41 (1952), 211.

49 Laura B Hamilton, Anthony Munday and the Catholics, 1560-1633 (Aldershot, Hants, 2005), 158.

50 Hill, Anthony Munday and Civic Culture, 75.

51 Ioppolo, Dramatists and Their Manuscripts, 101.

52 One exception to this almost universal practice is The Merry Wives of Windsor, which makes no reference back to the history plays and rather than being chronologically later seems to be set in a different time and world from its originals. Falstaff and his gang reappear in a totally new context like commedia or Disney cartoon characters. I'm not aware of any other instances of this in early modern English drama and it seems very unlikely that Munday would have used this technique in John a Kent.

53 Foakes (ed.), Henslowe's Diary, 181.

54 Ibid, 206.

55 Knutson, The Repertory of Shakespeare's Company, 90.

56 Thomas Middleton, The Black Book (1604), in Thomas Middleton, The Collected Works, ed. Gary Taylor and John Lavagnino (Oxford, 2007), 216.

57 Ben Jonson, The Devil Is an Ass, in Herford and Simpson (eds), Ben Jonson, 6.161270.

58 See the amusing Wikipedia article on 'Abie's Irish Rose'. 